\title{
Inhibitor-1 and -2 of PP2A have preference between PP2A complexes.
}

\author{
Hirotsugu Hino ${ }^{\text {a }}$ Kaori Takaki ${ }^{a}$ and Satoru Mochida ${ }^{\text {a,b,c,d, }, *}$
}

${ }^{a}$ Priority Organization for Innovation and Excellence,

${ }^{\mathrm{b}}$ Institute of Molecular Embryology and Genetics (IMEG) and

${ }^{\mathrm{c}}$ International Research Center for Medical Sciences (IRCMS), Kumamoto University,

Honjo-Kyoyotou, 2-2-1 Honjo, Chuo-ku, Kumamoto city, Kumamoto 860-0811, Japan

${ }^{\mathrm{d}}$ PRESTO Program, Japan Science and Technology agency, Japan

* Corresponding author: Tel/Fax +81-96-373-6819; E-mail: mochida@kumamoto-u.ac.jp

Abbreviations: PP2A, protein phosphatase $2 \mathrm{~A}$; $\mathrm{I}^{\mathrm{PP} 2 \mathrm{~A}}$, Inhibitor-1 of PP2A; $\mathrm{I}^{\mathrm{PP} 2 \mathrm{~A}}$, Inhibitor-2 of PP2A; PPP, phosphoprotein phosphatase; CSF, cyto-static factor; OA, okadaic acid 


\section{Abstract}

Protein phosphatase 2A (PP2A) forms tens of kinds of complexes with different substrate specificity and functions by using various regulatory B subunits. But how these complexes' activities are regulated separately is not well understood. Here we showed unequal enzyme inhibition of each form by two proteinous PP2A inhibitors, $\mathrm{I}^{\mathrm{PP} 2 \mathrm{~A}}$ and $\mathrm{I} 2^{\mathrm{PP} 2 \mathrm{~A}}$. Immunoprecipitation assay using Xenopus egg extract showed that $\mathrm{I}^{\mathrm{PP} 2 \mathrm{~A}}$ bound B"/PR48, and $\mathrm{I} 2^{\mathrm{PP} 2 \mathrm{~A}}$ bound $\mathrm{B} 56 \gamma$ and $\mathrm{B}$ "/PR48 among four B subunits analyzed. Thus $\mathrm{I}^{\mathrm{PP} 2 \mathrm{~A}}$ and $\mathrm{I}^{\mathrm{PP} 2 \mathrm{~A}}$ seem to have B-subunit specificity. These results support the hypothesis that PP2A complexes containing common catalytic subunit are individually regulated for their separate functions in vivo.

Keywords: PP2A; B-subunit specificity; $\mathrm{I}^{\mathrm{PP} 2 \mathrm{~A}} ; \mathrm{I}^{\mathrm{PP} 2 \mathrm{~A}}$; inhibitor protein 


\section{Introduction}

Protein phosphatase 2A (PP2A) is a member of phosphoprotein phosphatase (PPP) family serine/threonine phosphatases. PP2A acts as a trimeric holoenzyme consisting of catalytic C subunit, scaffolding A subunit and regulatory variable B subunit [1]. About 20 B subunits have been reported in human transcriptome. B subunits are classified, based on their sequence homology, into several sub-families including B55/B, B56/B', B" and B"'. It is believed that B subunits define intracellular localization and substrate specificity of the whole complexes, resulting in the various PP2A functions in multiple cellular events [2].

Cell cycle is a good example in which PP2A complexes containing different B subunits play separate functions. PP2A containing a B56 subunit (PP2A-B56) localizes to the pericentromeric region of chromosome and has important roles in regulation of chromosome separation [3,4]. PP2A-B55 is responsible for dephosphorylating a subset of cyclin-dependent kinase (CDK) substrates $[5,6,7,8,9]$. These two PP2A complexes are regulated during cell cycle at spatial and/or activity levels by different mechanisms $[3,4,10,11,12,13]$.

Of known PP2A inhibitor proteins, Inhibitor-1 and -2 of PP2A $\left(\mathrm{I}^{\mathrm{PP} 2 \mathrm{~A}}\right.$ and $\left.\mathrm{I} 2^{\mathrm{PP} 2 \mathrm{~A}}\right)$ have been biochemically identified from supernatant of boiled kidney lysate [14]. I1 ${ }^{\mathrm{PP} 2 \mathrm{~A}}$ is also known as LANP, pp32, PHAP-I, mapmodulin and Anp32A and has been reported to be involved in tumor suppression [15,16,17], cell-mediated cytotoxicity [18], signal transduction [19], regulation of microtubule function and microtubule-based vesicular trafficking [20,21,22]. $\mathrm{I}^{\mathrm{PP} 2 \mathrm{~A}}$ also has several names, such as SET, TAF-1 $\beta$, IGAAD and PHAP-II and is involved in cell cycle [23], cell proliferation [24], cell motility [25] and control of gene transcription [26,27]. These observations suggest that $\mathrm{I}^{\mathrm{PP} 2 \mathrm{~A}}$ and $\mathrm{I} 2^{\mathrm{PP} 2 \mathrm{~A}}$ are implicated in many cellular events.

It is still not clear if $\mathrm{I}^{\mathrm{PP} 2 \mathrm{~A}}$ and $\mathrm{I}^{\mathrm{PP} 2 \mathrm{~A}}$ target only $\mathrm{PP} 2 \mathrm{~A}$ complexes containing a certain kind of B subunit or they inhibit all kinds of PP2A complexes. In the previous studies, PP2A monomer of $\mathrm{C}$ subunit, dimer consisting of $\mathrm{A}$ and $\mathrm{C}$ subunits and one trimeric complex (maybe containing B55) have been used in their in vitro assays [14,28,29]. As such, little is known about 
B-subunit specificity of $\mathrm{I} 1^{\mathrm{PP} 2 \mathrm{~A}}$ and $\mathrm{I} 2^{\mathrm{PP} 2 \mathrm{~A}}$. Because $\mathrm{B}$ subunit is the functional determinant of whole PP2A complex as described above, it is hard to imagine that all kinds of PP2A complexes are regulated by single inhibitor proteins at one time.

In this study, we aimed to test if $\mathrm{I}^{\mathrm{PP} 2 \mathrm{~A}}$ and $\mathrm{I}^{\mathrm{PP} 2 \mathrm{~A}}$ have any B-subunit specificity. $\mathrm{I}^{\mathrm{PP} 2 \mathrm{~A}}$ and $2^{\mathrm{PP} 2 \mathrm{~A}}$ physically interacted with two of four B subunits analyzed. PP2A inhibition assay also suggested B-subunit specificity of $\mathrm{I}^{\mathrm{PP} 2 \mathrm{~A}}$ and $\mathrm{I}^{\mathrm{PP} 2 \mathrm{~A}}$, implying that most, if not all, PP2A complexes containing different B subunits could be regulated separately by specific inhibitor proteins for their separate functions in vivo. 


\section{Materials and Methods}

\section{Xenopus egg extract}

Interphase extract made of parthenogenetically activated egg and cytostatic factor-arrested (CSF) extract were prepared as described [30,31].

\section{Recombinant proteins}

The cDNA fragments encoding Xenopus laevis full length $\mathrm{I}^{\mathrm{PP} 2 \mathrm{~A}}$ and $\mathrm{I}^{\mathrm{P} 2 \mathrm{~A}}$ were inserted into pET16b vector (Novagen). Recombinant proteins of histidine (His) tagged I1 ${ }^{\mathrm{PP} 2 \mathrm{~A}}$ and $2_{2}^{\mathrm{PP} 2 \mathrm{~A}}$ were expressed in E. coli BL21-CodonPlus(DE3)-RP strain (Agilent Technologies) and purified with HisPur Ni-NTA Resin (Thermo Scientific). Recombinant PP2A complexes were prepared as described previously with some modification [8]. Untagged $\mathrm{C} \beta$, glutathione S-transferase (GST) tagged A $\alpha$ and His-tagged B55, , His-tagged B56 $\gamma$ or His-tagged B'"/PR48 subunits of PP2A (all from Xenopus laevis cDNA except B558, which is from rat) were coexpressed in HighFive cells using pFastBac baculovirus expression system (Life Technologies). Infected cells were extracted in an extraction buffer (50 mM Tris- $\mathrm{HCl}, 150 \mathrm{mM}$ $\mathrm{NaCl}, 0.5 \mathrm{mM}$ dithiothreitol (DTT), 0.1\% Tween-20, 1 mM EDTA, 1 mM EGTA, 5\% glycerol, $0.5 \mathrm{mM}$ benzamidine, $0.5 \mathrm{mM}$ phenylmethanesulfonyl fluoride, $\mathrm{pH} 7.5$ ) by rotating $20 \mathrm{~min}$ at $4^{\circ} \mathrm{C}$, followed by sonication. From cleared cell lysates, PP2A complex was purified on Glutathione Sepharose 4B (GE Healthcare). GST tag was cleaved off by Rhinovirus 3C protease. Eluted proteins were next purified on Ni-NTA Resin (Thermo Scientific) to ensure that all complexes contained B subunit. For preparation of PP2A dimer, only C $\beta$ and GST-tagged A $\alpha$ subunits were coexpressed. These purified proteins were quantified by comparing with BSA on Coomassie Brilliant Blue (CBB)-stained gels. For PP2A complexes, concentration of C subunit was used.

\section{Antibodies}


Anti-PP2A C $\beta$, B55 $\delta$, B56 $\gamma$, B56 $\varepsilon$ and B"/PR48 antisera have been reported previously [8]. Affinity purified antibodies from these antisera were used for immunoblotting. For $\mathrm{I}^{\mathrm{PP} 2 \mathrm{~A}}$ and $\mathrm{I}^{\mathrm{PP} 2 \mathrm{~A}}$ antibodies, His-tagged full-length proteins expressed in bacteria were injected into rabbits (BioGenes).

\section{PP2A binding to heat-stable fraction}

To prepare heat-stable fraction, Xenopus egg interphase extract supplemented with cycloheximide was incubated with or without $2 \mu \mathrm{M}$ okadaic acid (OA, potassium salt, LC Laboratories) for $30 \mathrm{~min}$ at $23^{\circ} \mathrm{C}$. The extract was diluted by one-third volume of phosphate-buffered saline and heated for $5 \mathrm{~min}$ at $95^{\circ} \mathrm{C}$. Supernatant after centrifugation $(5 \mathrm{~min}$ at $4^{\circ} \mathrm{C}, 21,130 \times g$ ) was retrieved. The supernatant was treated by RNase A (Takara) for $1 \mathrm{~h}$ at $37^{\circ} \mathrm{C}$ and then desalted by PD-10 Desalting Column (GE Healthcare) to remove small molecules such as nucleotides. After concentration by Amicon Ultra filter unit (3,000 nominal molecular weight limit, Merck Millipore), the retained fraction was covalently conjugated to CNBr-activated Sepharose 4B resin (GE Healthcare) according to the manufacture's protocol. After conjugation, extra active groups on the resin were blocked by adding wash buffer $(20 \mathrm{mM}$ Tris- $\mathrm{HCl}, 150 \mathrm{mM} \mathrm{NaCl}, 0.05 \%$ Tween-20, $\mathrm{pH}$ 7.5). The resin was separated into two halves and one was treated with lambda protein phosphatase (New England BioLabs) according to the manufacture's protocol. To reduce non-specific binding, all resin was treated with blocking buffer (same as the wash buffer but contains 3\% BSA) before use. The resin was mixed with fresh interphase egg extract and incubated with gentle agitation for 30 min at $4{ }^{\circ} \mathrm{C}$. After washing with the wash buffer, resin-bound proteins were analyzed for PP2A subunits by immunoblotting.

\section{Substrate for PP2A inhibition assay}

Two hundred micrograms of myelin basic protein (MBP, bovine, Merck Millipore) 
was incubated with 4,500 units of cAMP-dependent protein kinase (PKA, catalytic subunit, New England BioLabs), $15 \mu \mathrm{L}$ of $\left[\gamma_{-}{ }^{32} \mathrm{P}\right] \mathrm{ATP}(25 \mu \mathrm{M}, 222 \mathrm{TBq} / \mathrm{mmol}$, PerkinElmer $), 1 \mathrm{mM}$ ATP, $1 \times$ PKA buffer (50 mM Tris- $\mathrm{HCl}, 10 \mathrm{mM} \mathrm{MgCl} 2,5 \mathrm{mM} \mathrm{NaF}, 5 \mathrm{mM}$ EGTA, $20 \mathrm{mM}$ $\beta$-glycerophosphate, $1 \mathrm{mM} \mathrm{DTT}$, $\mathrm{pH} 7.5$ ) in a final volume of $70 \mu \mathrm{l}$ overnight at $37^{\circ} \mathrm{C}$. Phosphorylated MBP was precipitated with $16 \%$ trichloroacetic acid, washed with $95 \%$ ethanol and dissolved in $160 \mu \mathrm{l}$ of substrate buffer (50 mM Tris-HCl, $1 \mathrm{mM}$ DTT, 3\% glycerol, $\mathrm{pH}$ 7.0). The phosphorylated MBP was quantified by comparing with known amount of unlabeled MBP on a CBB-stained gel.

\section{PP2A inhibition assay}

In vitro PP2A inhibition assay was performed as described [14,29] with minor modifications. In brief, various concentrations of inhibitor proteins ( $\mathrm{I} 1^{\mathrm{PP} 2 \mathrm{~A}}$ or $\mathrm{I} 2^{\mathrm{PP} 2 \mathrm{~A}}$ ) and 0.2 fmol of PP2A complex were mixed in phosphatase buffer $(50 \mathrm{mM}$ Tris- $\mathrm{HCl}, 0.05 \mathrm{mg} / \mathrm{ml}$ BSA, 1 $\mathrm{mM}$ DTT, $0.25 \mathrm{mM} \mathrm{MnCl}_{2}, \mathrm{pH} 7.0$ ) and preincubated at $30^{\circ} \mathrm{C}$ for $10 \mathrm{~min}$ before adding phosphorylated substrate. After preincubation, 4 ng of ${ }^{32} \mathrm{P}$-labeled substrate diluted in the phosphatase buffer was added to the mixture. Total reaction volume was $10 \mu 1$ and phosphatase

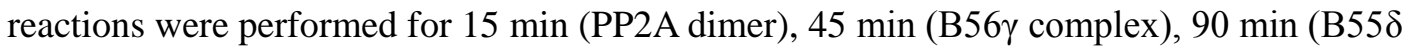
complex) and $240 \mathrm{~min}\left(\mathrm{~B}\right.$ / $/ \mathrm{PR} 48$ complex) at $30^{\circ} \mathrm{C}$, respectively. Reactions were stopped by adding $50 \mu 1$ of $20 \%$ trichloroacetic acid and radioactivity released from the substrate was measured as described [32]. Curve fitting used for Fig. 3B and C were done by using the four parameter logistic model (also called the sigmoidal dose-response model):

$y=A+(B-A) /\left(1+(x / C)^{\wedge} D\right)$

where $y$ is the percentage activity with the value of PP2A activity without inhibitor proteins as $100 \%$ and $x$ is the corresponding concentration of inhibitor proteins in $\mathrm{nM}$. The fitting $C$ parameter is the $50 \%$ inhibitory concentration and the slope $(D)$ is assigned to be $1, A$ is 0 and $B$ is 100 . 


\section{Results}

\section{PP2A bound endogenous heat-stable factors depending on these factors' phosphorylation}

state.

We first tested a hypothesis that endogenous inhibitors for PP2A bind and regulate the activity of cellular PP2A complexes. To this end, we determined the PP2A binding activity in the heat-stable fractions of egg extracts as outlined in Fig. 1A, because many inhibitor proteins for protein phosphatase 1 (PP1) and PP2A have been identified from heat-stable fraction of cell extract $[14,33,34]$. Interphase egg extract treated with or without OA was boiled and centrifuged to retrieve heat-stable factors (supernatant) from precipitated aggregates. OA is a potent inhibitor for most of PPP family phosphatases, thereby induces massive protein phosphorylation including mitotic ones $[8,35,36,37]$. The heat-stable fraction was next gel-filtrated and mixed with cyanogen bromide resin to conjugate any primary amino group-containing molecules. The resin was then incubated with fresh interphase egg extract to see if any PP2A subunits bound the resin. As a result, all the four B subunits of PP2A analyzed and the catalytic C subunit bound the resin (Fig. 1B lane 3, compared with lane 2, a BSA-conjugated resin). The interaction was enhanced when resin was conjugated with heat-stable fraction of OA-treated egg extract (lane 4). Prior lambda phosphatase treatment of the resin weakened the interaction with all the B subunits (lane 5). These results suggest that the heat-stable fraction of egg extract contains factors that physically interact with the PP2A, likely via the B subunits, and that these interactions are regulated by phosphorylation of the heat-stable factors. The binding property of B55 $\delta$ is consistent with the previous finding that heat-stable phosphorylatable proteins bind and inhibit PP2A-B55 (Fig. 1B) [10,11].

$\mathrm{I1}^{\mathrm{PP} 2 \mathrm{~A}}$ and $\mathrm{I}^{\mathrm{PP} 2 \mathrm{~A}}$ showed binding specificity to $\mathrm{B}$ subunits of PP2A. 
$\mathrm{I} 1^{\mathrm{PP} 2 \mathrm{~A}}$ and $\mathrm{I}^{\mathrm{PP} 2 \mathrm{~A}}$ have been reported to be heat-stable [14], so they are likely candidates that caused the physical interaction of the heat-stable factors with B56 $\gamma$, B $56 \varepsilon$ and $\mathrm{B}$ "/PR48. Therefore, we next tested if $\mathrm{I}^{\mathrm{PP} 2 \mathrm{~A}}$ and $\mathrm{I}^{\mathrm{PP} 2 \mathrm{~A}}$ were expressed in Xenopus eggs, and if they were included in the heat-stable fraction. We raised rabbit polyclonal antibodies against the full-length proteins of Xenopus $\mathrm{I}^{\mathrm{PP} 2 \mathrm{~A}}$ and $\mathrm{I}^{\mathrm{PP} 2 \mathrm{~A}}$. Affinity-purified antibodies against $\mathrm{I}^{\mathrm{PP} 2 \mathrm{~A}}$ and $\mathrm{I} 2^{\mathrm{PP} 2 \mathrm{~A}}$ recognized endogenous proteins (Fig. $1 \mathrm{C}$ and D). Xenopus $\mathrm{I} 1^{\mathrm{PP} 2 \mathrm{~A}}$ and $\mathrm{I}^{\mathrm{PP} 2 \mathrm{~A}}$ were also found to be heat-stable, consistent with the previous report (Fig. 1E) [14]. These results suggest that $\mathrm{I} 1^{\mathrm{PP} 2 \mathrm{~A}}$ and $\mathrm{I}^{\mathrm{PP} 2 \mathrm{~A}}$ are partly responsible for the interaction of the heat-stable fraction with PP2A subunits.

To test physical interactions between PP2A subunits and $\mathrm{I}^{\mathrm{PP} 2 \mathrm{~A}}$ or $\mathrm{I}^{\mathrm{PP} 2 \mathrm{~A}}$ more directly, immunoprecipitation assay was performed. Because OA-treatment enhanced the interaction between heat-stable fraction and PP2A subunits (Fig. 1B), the assay was performed using interphase egg extract in the presence of OA. As a result, B'/PR48 was coprecipitated with I1 ${ }^{\mathrm{PP} 2 \mathrm{~A}}$ (Fig. 2A, lane 3), and B56 $\gamma$ and B''/PR48 were coprecipitated with $2^{\mathrm{PP} 2 \mathrm{~A}}$ (lane 4). Neither B55 $\delta$ nor B56 $\varepsilon$ was precipitated by anti-I1 ${ }^{\mathrm{PP} 2 \mathrm{~A}}$ and $-\mathrm{I} 2^{\mathrm{PP} 2 \mathrm{~A}}$ antibodies, confirming previous reports $[38,39]$. These results suggest that $\mathrm{I}^{\mathrm{PP} 2 \mathrm{~A}}$ and $\mathrm{I}^{\mathrm{PP} 2 \mathrm{~A}}$ recognize $\mathrm{B}$ subunits associated with PP2A.

Next we asked if these physical interactions are regulated during cell cycle. To answer this question, we performed an immunoprecipitation assay in interphase (hypo-phosphorylated) and CSF extracts (mitotically phosphorylated) (Fig. 2B). B56 $\gamma$ was coprecipitated with I2 ${ }^{\mathrm{PP} 2 \mathrm{~A}}$ both in interphase and CSF extracts (lanes 7 and 8). B"/PR48 was coprecipitated with $\mathrm{I}^{\mathrm{PP} 2 \mathrm{~A}}$ and $\mathrm{I}^{\mathrm{PP} 2 \mathrm{~A}}$ in CSF extract, but very weakly in interphase extract (lanes 5-8). This result, together with Fig. 2A, indicates that B"/PR48's binding to $\mathrm{I} 1^{\mathrm{PP} 2 \mathrm{~A}}$ and $\mathrm{I}^{\mathrm{PP} 2 \mathrm{~A}}$ is cell-cycle regulated. We also found that B56 $\gamma$ and B"/PR48 showed lower mobility in CSF extract than in interphase on a phos-tag gel, suggesting their phosphorylation in CSF extract (Fig. 2C). 


\section{Inhibition by $\mathrm{I}^{\mathrm{PP2A}}$ and $\mathrm{I}^{\mathrm{PP2A}}$ are affected by B subunit of PP2A.}

Next we tested if PP2A inhibition by $\mathrm{I}^{\mathrm{PP} 2 \mathrm{~A}}$ and $2^{\mathrm{PP} 2 \mathrm{~A}}$ is affected in vitro by its $\mathrm{B}$ subunit included. Using recombinant PP2A complexes purified from insect cells, PP2A inhibition assay was performed in the presence of recombinant $\mathrm{I} 1^{\mathrm{PP} 2 \mathrm{~A}}$ and $\mathrm{I}^{\mathrm{PP} 2 \mathrm{~A}}$ (Fig. 3A). Inhibition of PP2A-B55 by $\mathrm{I}^{\mathrm{PP} 2 \mathrm{~A}}$ was weaker than that of PP2A-B56 $\gamma,-\mathrm{B}$ ' $/ \mathrm{PR} 48$ and PP2A dimer, which consists of A and C subunits (Fig. 3B). Inhibition of PP2A-B55 $\delta$ and -B56 $\gamma$ by ${ }^{\mathrm{I}} 2^{\mathrm{PP} 2 \mathrm{~A}}$ were weaker than that of PP2A-B'"/PR48 and dimer (Fig. 3C). Thus, inhibition by $1^{\mathrm{PP} 2 \mathrm{~A}}$ and $\mathrm{I}^{\mathrm{PP} 2 \mathrm{~A}}$ are affected by B subunit of PP2A. We also noted that form of the inhibition curve of $\mathrm{I} 2^{\mathrm{PP} 2 \mathrm{~A}}$ for PP2A-B56 $\gamma$ was different from that for the other PP2A complexes. 


\section{Discussion}

In this study, we demonstrated that $\mathrm{I}^{\mathrm{PP} 2 \mathrm{~A}}$ and $\mathrm{I} 2^{\mathrm{PP} 2 \mathrm{~A}}$ have preference between PP2A complexes. This conclusion was led by the immunoprecipitation assay and the PP2A inhibition assay (Fig. 2 and 3, summarized in Table 1). In the former, I1 ${ }^{\mathrm{PP} 2 \mathrm{~A}}$ associated with B"/PR48, and $\mathrm{I} 2^{\mathrm{PP} 2 \mathrm{~A}}$ associated with $\mathrm{B} 56 \gamma$ and B"/PR48. In the latter, I1 ${ }^{\mathrm{PP} 2 \mathrm{~A}}$ more potently inhibited B56 $\gamma$ and B"/PR48 than B55 $\delta$, whereas I2 ${ }^{\mathrm{PP} 2 \mathrm{~A}}$ preferred B"/PR48 to B55 $\delta$ or B56 $\gamma$. These are consistent with the idea that PP2A complexes containing different B subunit should be regulated by distinct mechanisms for their separate functions in vivo. In addition, each of $\mathrm{A}$ and $\mathrm{C}$ subunits of PP2A has two isoforms ( $\alpha$ and $\beta$ ), further increasing the number of possible PP2A complex species.

Accumulating evidence suggests that phosphorylation of PP2A inhibitors/regulators affects their potency. Alpha-endosulfine, ARPP-19 (both B55 specific) and Bod1 (B56 specific) are phosphorylated and thereby activated for PP2A inhibition $[12,40,41] .1^{\mathrm{PP} 2 \mathrm{~A}}$ has been reported to be phosphorylated at its serines 158 and 204 [42], although effect of these phosphorylations is still unknown. $\mathrm{I}^{\mathrm{PP} 2 \mathrm{~A}}$ was also shown to be phosphorylated at serines 9 and $171[29,43]$, and these phosphorylations have positive and negative effects on $\mathrm{I}^{\mathrm{PP} 2 \mathrm{~A}}$, s potency for PP2A inhibition, respectively $[25,29,44,45]$. I2 ${ }^{\mathrm{PP} 2 \mathrm{~A}}$ phosphorylation at serine 9 causes a change of its intracellular localization, and mutant $\mathrm{I} 2^{\mathrm{PP} 2 \mathrm{~A}}$ proteins substituted of serine 9 with phospho-mimetic amino acids associate with PP2A more strongly than wildtype. Inhibition of PP2A activity observed in Fig. 3 could be affected by such post-translational modification of $\mathrm{I} 1^{\mathrm{PP} 2 \mathrm{~A}}$ and $\mathrm{I} 2^{\mathrm{PP} 2 \mathrm{~A}}$, because recombinant inhibitor proteins purified from bacteria were used in the experiment. B56 $\gamma$ did not show detectable physical interaction with $\mathrm{I1}^{\mathrm{PP} 2 \mathrm{~A}}$, but PP2A-B56 $\gamma$ was inhibited by $\mathrm{I}^{\mathrm{PP} 2 \mathrm{~A}}$ as strong as PP2A-B"/PR48 was, which interacts with $\mathrm{I1}^{\mathrm{PP} 2 \mathrm{~A}}$. B56 $\gamma$ interacted with $\mathrm{I}^{\mathrm{PP} 2 \mathrm{~A}}$, but PP2A-B56 $\gamma$ was inhibited by $\mathrm{I}^{\mathrm{PP} 2 \mathrm{~A}}$ as weak as PP2A-B55 $\delta$ was, which does not interact with $\mathrm{I}^{\mathrm{PP} 2 \mathrm{~A}}$. These apparent discrepancies of experimental data again suggest an importance of post-translational modification of inhibitor proteins. 
We observed that all the B subunits analyzed physically interacted with heat-stable factors of egg extract and this interaction was affected more or less by phosphorylation status of the heat-stable factors (Fig. 1B). Enhanced interactions between B"/PR48 and I1 ${ }^{\mathrm{PP} 2 \mathrm{~A}}$ and $2^{\mathrm{PP} 2 \mathrm{~A}}$ during $\mathrm{M}$ phase imply phospho-dependent regulation of $\mathrm{I}^{\mathrm{PP} 2 \mathrm{~A}}$ and $\mathrm{I}^{\mathrm{PP} 2 \mathrm{~A}}$ (Fig. 2B), although we could not confirm phosphorylation of $\mathrm{I} 1^{\mathrm{PP} 2 \mathrm{~A}}$ and $\mathrm{I} 2^{\mathrm{PP} 2 \mathrm{~A}}$ by using SDS polyacrylamide gel containing phos-tag reagent (data not shown). Interestingly, we found that B"/PR48 (and B56 $\gamma$ ) were phosphorylated in M phase, but not in interphase (Fig. 2C). So it is also possible that phosphorylation of B subunits make them susceptible to the influence of $\mathrm{I}^{\mathrm{PP} 2 \mathrm{~A}}$ and $\mathrm{I} 2^{\mathrm{PP} 2 \mathrm{~A}}$. Factor(s) that interacts with B56e is also regulated by phosphorylation, but its identity is still not known (Fig. 1B). Bod1 is one of possible candidates for this [12]. But we believe that there are more PP2A regulators to be identified, because new PP2A regulators have been identified in the recent years.

We speculate that there must be many more inhibitor (or activator) molecules for PP2A unexplored and other modes of PP2A regulation such as intracellular localization. As for serine/threonine-specific catalytic subunits, gene number of protein kinases is 4- to 5-times more than that of protein phosphatases [46]. The variety of PP2A complexes would partly compensate for this big difference. If so, each PP2A complex should be regulated apart from others. Compared with the variety of PP2A complexes, however, only several endogenous inhibitors are known to date. Inhibition of phosphatase coordinated with activation of kinase is important, especially when a substrate needs to be completely and/or continuously phosphorylated. Our knowledge of protein phosphatase regulation is still far behind that of protein kinases. 


\section{Acknowledgement}

We are grateful to Dr. Masumi Eto (Thomas Jefferson University), Prof. Greg Moorhead and Ms. Isha Nasa (University of Calgary) for careful reading of the manuscript and advice and to Prof. Yasuharu Nishimura and Dr. Atsushi Irie (Kumamoto University) for technical advice of PP2A inhibition assay. We also thank all the lab members, the Institute of Molecular Embryology and Genetics (IMEG) and the Radio Isotope Center (RIC) of Kumamoto University for practical support of the experiments. This work was supported by the PRESTO program of the Japan Science and Technology Agency. 


\section{References}

[1] D.M. Virshup, S. Shenolikar, From promiscuity to precision: protein phosphatases get a makeover, Mol. Cell 33 (2009) 537-545.

[2] V. Janssens, J. Goris, Protein phosphatase 2A: a highly regulated family of serine/threonine phosphatases implicated in cell growth and signalling, Biochem. J. 353 (2001) 417-439.

[3] T.S. Kitajima, T. Sakuno, K. Ishiguro, et al., Shugoshin collaborates with protein phosphatase 2A to protect cohesin, Nature 441 (2006) 46-52.

[4] C.G. Riedel, V.L. Katis, Y. Katou, et al., Protein phosphatase 2A protects centromeric sister chromatid cohesion during meiosis I, Nature 441 (2006) 53-61.

[5] P. Ferrigno, T.A. Langan, P. Cohen, Protein phosphatase $2 \mathrm{~A}_{1}$ is the major enzyme in vertebrate cell extracts that dephosphorylates several physiological substrates for cyclin-dependent protein kinases, Mol. Biol. Cell 4 (1993) 669-677.

[6] R.E. Mayer-Jaekel, H. Ohkura, R. Gomes, et al., The 55 kd regulatory subunit of Drosophila protein phosphatase 2A is required for anaphase, Cell 72 (1993) 621-633.

[7] R.E. Mayer-Jaekel, H. Ohkura, P. Ferrigno, et al., Drosophila mutants in the $55 \mathrm{kDa}$ regulatory subunit of protein phosphatase $2 \mathrm{~A}$ show strongly reduced ability to dephosphorylate substrates of p34 ${ }^{\text {cdc2 }}$ J. Cell Sci. 107 (1994) 2609-2616.

[8] S. Mochida, S. Ikeo, J. Gannon, et al., Regulated activity of PP2A-B55 $\delta$ is crucial for controlling entry into and exit from mitosis in Xenopus egg extracts, EMBO J. 28 
(2009) 2777-2785.

[9] M.H. Schmitz, M. Held, V. Janssens, et al., Live-cell imaging RNAi screen identifies PP2A-B55 $\alpha$ and importin- $\beta 1$ as key mitotic exit regulators in human cells, Nat. Cell Biol. 12 (2010) 886-893.

[10] S. Mochida, S.L. Maslen, M. Skehel, et al., Greatwall phosphorylates an inhibitor of protein phosphatase 2A that is essential for mitosis, Science 330 (2010) 1670-1673.

[11] A. Gharbi-Ayachi, J.C. Labbé, A. Burgess, et al., The substrate of Greatwall kinase, Arpp19, controls mitosis by inhibiting protein phosphatase 2A, Science 330 (2010) $1673-1677$.

[12] I.M. Porter, K. Schleicher, M. Porter, et al., Bod1 regulates protein phosphatase 2A at mitotic kinetochores, Nat. Commun. 4 (2013) 2677.

[13] A. Grallert, E. Boke, A. Hagting, et al., A PP1-PP2A phosphatase relay controls mitotic progression, Nature 517 (2015) 94-98.

[14] M. Li, H. Guo, Z. Damuni, Purification and characterization of two potent heat-stable protein inhibitors of protein phosphatase 2A from bovine kidney, Biochemistry 34 (1995) 1988-1996.

[15] T.H. Chen, J.R. Brody, F.E. Romantsev, et al., Structure of pp32, an acidic nuclear protein which inhibits oncogene-induced formation of transformed foci, Mol. Biol. Cell 7 (1996) 2045-2056. 
[16] J.R. Brody, S.S. Kadkol, M.A. Mahmoud, et al., Identification of sequences required for inhibition of oncogene-mediated transformation by pp32, J. Biol. Chem. 274 (1999) 20053-20055.

[17] J. Bai, J.R. Brody, S.S. Kadkol, et al., Tumor suppression and potentiation by manipulation of pp32 expression, Oncogene 20 (2001) 2153-2160.

[18] P.J. Beresford, C.M. Kam, J.C. Powers, et al., Recombinant human granzyme A binds to two putative HLA-associated proteins and cleaves one of them, Proc. Natl. Acad. Sci. USA 94 (1997) 9285-9290.

[19] M. Vaesen, S. Barnikol-Watanabe, H. Götz, et al., Purification and characterization of two putative HLA class II associated proteins: PHAPI and PHAPII, Biol. Chem. Hoppe Seyler 375 (1994) 113-126.

[20] N. Ulitzur, M. Humbert, S.R. Pfeffer, Mapmodulin: a possible modulator of the interaction of microtubule-associated proteins with microtubules, Proc. Natl. Acad. Sci. USA 94 (1997) 5084-5089.

[21] N. Ulitzur, C. Rancano, S.R. Pfeffer, Biochemical characterization of mapmodulin, a protein that binds microtubule-associated proteins, J. Biol. Chem. 272 (1997) 30577-30582.

[22] C. Itin, N. Ulitzur, B. Mühlbauer, et al., Mapmodulin, cytoplasmic dynein, and microtubules enhance the transport of mannose 6-phosphate receptors from endosomes to the trans-golgi network, Mol. Biol. Cell 10 (1999) 2191-2197. 
[23] N. Canela, A. Rodriguez-Vilarrupla, J.M. Estanyol, et al., The SET protein regulates $\mathrm{G}_{2} / \mathrm{M}$ transition by modulating cyclin B-cyclin-dependent kinase 1 activity, J. Biol. Chem. 278 (2003) 1158-1164.

[24] K.S. Shin, E.Y. Shin, S.C. Bae, et al., Expression of SET is modulated as a function of cell proliferation, J. Cell. Biochem. 74 (1999) 119-126.

[25] J.P. ten Klooster, I. Leeuwen, N. Scheres, et al., Rac1-induced cell migration requires membrane recruitment of the nuclear oncogene SET, EMBO J. 26 (2007) 336-345.

[26] N.A. Compagnone, P. Zhang, J.L. Vigne, et al., Novel role for the nuclear phosphoprotein SET in transcriptional activation of P450c17 and initiation of neurosteroidogenesis, Mol. Endocrinol. 14 (2000) 875-888.

[27] S.B. Seo, P. McNamara, S. Heo, et al., Regulation of histone acetylation and transcription by INHAT, a human cellular complex containing the set oncoprotein, Cell 104 (2001) 119-130.

[28] M. Li, A. Makkinje, Z. Damuni, The myeloid leukemia-associated protein SET is a potent inhibitor of protein phosphatase 2A, J. Biol. Chem. 271 (1996) 11059-11062.

[29] A. Irie, K. Harada, N. Araki, et al., Phosphorylation of SET protein at Ser171 by protein kinase D2 diminishes its inhibitory effect on protein phosphatase 2A, PLoS One 7 (2012) e51242.

[30] K. Ohsumi, T.M. Yamamoto, M. Iwabuchi, Oocyte extracts for the study of meiotic M-M 
transition, Methods Mol. Biol. 322 (2006) 445-458.

[31] A.W. Murray, M.J. Solomon, M.W. Kirschner, The role of cyclin synthesis and degradation in the control of maturation promoting factor activity, Nature 339 (1989) 280-286.

[32] S. Mochida, T. Hunt, Calcineurin is required to release Xenopus egg extracts from meiotic M phase, Nature 449 (2007) 336-340.

[33] F.L. Huang, W.H. Glinsmann, Separation and characterization of two phosphorylase phosphatase inhibitors from rabbit skeletal muscle, Eur. J. Biochem. 70 (1976) 419-426.

[34] J. Zhang, L. Zhang, S. Zhao, et al., Identification and characterization of the human HCG V gene product as a novel inhibitor of protein phosphatase-1, Biochemistry 37 (1998) 16728-16734.

[35] K. Tachibana, P.J. Scheuer, Y. Tsukitani, et al., Okadaic acid, a cyto-toxic polyether from two marine sponges of the genus Halichondria, J. Am. Chem. Soc. 103 (1981) 2469-2471.

[36] A. Takai, C. Bialojan, M. Troschka, et al., Smooth muscle myosin phosphatase inhibition and force enhancement by black sponge toxin, FEBS Lett. 217 (1987) 81-84.

[37] C. Bialojan, A. Takai, Inhibitory effect of a marine-sponge toxin, okadaic acid, on protein phosphatases. Specificity and kinetics, Biochem. J. 256 (1988) 283-290.

[38] S. Chen, B. Li, I. Grundke-Iqbal, et al., $\mathrm{I}_{1}{ }^{\mathrm{P} 2 \mathrm{~A}}$ affects tau phosphorylation via association 
with the catalytic subunit of protein phosphatase 2A, J. Biol. Chem. 283 (2008) 10513-10521.

[39] L. Arnaud, S. Chen, F. Liu, et al., Mechanism of inhibition of PP2A activity and abnormal hyperphosphorylation of tau by $\mathrm{I}_{2}^{\mathrm{PP2A}} / \mathrm{SET}$, FEBS Lett. 585 (2011) 2653-2659.

[40] S. Mochida, Regulation of $\alpha$-endosulfine, an inhibitor of protein phosphatase 2A, by multisite phosphorylation, FEBS J. 281 (2014) 1159-1169.

[41] A.M. Labandera, A.R. Vahab, S. Chaudhuri, et al., The mitotic PP2A regulator ENSA/ARPP-19 is remarkably conserved across plants and most eukaryotes, Biochem. Biophys. Res. Commun. 458 (2015) 739-744.

[42] R. Hong, T. Macfarlan, S.N. Kutney, et al., The identification of phosphorylation sites of pp32 and biochemical purification of a cellular pp32-kinase, Biochemistry 43 (2004) $10157-10165$.

[43] Y. Adachi, G.N. Pavlakis, T.D. Copeland, Identification of in vivo phosphorylation sites of SET, a nuclear phosphoprotein encoded by the translocation breakpoint in acute undifferentiated leukemia, FEBS Lett. 340 (1994) 231-235.

[44] N.T. Vasudevan, M.L. Mohan, M.K. Gupta, et al., Inhibition of protein phosphatase 2A activity by PI3K $\gamma$ regulates $\beta$-adrenergic receptor function, Mol. Cell 41 (2011) $636-648$

[45] G. Yu, T. Yan, Y. Feng, et al., Ser9 phosphorylation causes cytoplasmic detention of 
$\mathrm{I}_{2}{ }^{\mathrm{PP} 2 \mathrm{~A}} / \mathrm{SET}$ in Alzheimer disease, Neurobiol. Aging 34 (2013) 1748-1758.

[46] F. Sacco, L. Perfetto, L. Castagnoli, et al., The human phosphatase interactome: An intricate family portrait, FEBS Lett. 586 (2012) 2732-2739. 


\section{Figure legends}

\section{Fig. 1 Heat-stable factors of Xenopus egg extract bound PP2A in}

phosphorylation-dependent and -independent manners.

(A) Schematic diagram of preparation of heat-stable factors-conjugated resin. Heat-stable fraction of interphase egg extract (Int) treated with or without OA was conjugated to cyanogen bromide-activated resin. The resin with or without lambda protein phosphatase ( $\lambda$ PPase) treatment was then mixed with fresh egg extract to see any physical interaction with PP2A subunits. (B) PP2A subunits associated with the resin were detected by immunoblotting (IB). BSA-conjugated resin was used as a negative control (lane 2). Arrowhead indicates B56 $\gamma$ and asterisk indicates a cross-reacting band. Signal intensity of each band was quantified by using ImageJ software (1.48v, National Institutes of Health, USA), and was shown below. (C)(D)(E) Antibodies raised against Xenopus $\mathrm{I}^{\mathrm{PP} 2 \mathrm{~A}}$ and $\mathrm{I}^{\mathrm{PP} 2 \mathrm{~A}}$ were affinity-purified, and used for immunoblotting to detect endogenous proteins in interphase egg extract $(\mathrm{C}$ and $\mathrm{D})$ and heat-stable fraction of the same extract (E). Molecular weight markers are shown in kDa. Experiments were performed at least twice.

Fig. $2 \mathrm{I}^{\mathrm{PP} 2 \mathrm{~A}}$ and $\mathrm{I}^{\mathrm{PP} 2 \mathrm{~A}}$ showed binding specificity to $\mathrm{B}$ subunits of PP2A.

(A) $\mathrm{I}^{\mathrm{PP} 2 \mathrm{~A}}$ and $\mathrm{I} 2^{\mathrm{PP} 2 \mathrm{~A}}$ were immunoprecipitated from interphase egg extract that was treated with OA for $30 \mathrm{~min}$ at $23^{\circ} \mathrm{C}$. After washing with wash buffer (see Materials and Methods), associated proteins were detected by immunoblotting using the indicated antibodies. Ctr is a control sample prepared by using unrelated rabbit serum (lane 2). The signal in lane 2 of B56e blot is IgG heavy chain. (B) $\mathrm{I}^{\mathrm{PP} 2 \mathrm{~A}}$ and $\mathrm{I}^{\mathrm{PP} 2 \mathrm{~A}}$ were immunoprecipitated from interphase egg extract (Int) or CSF extract (CSF). Samples were analyzed as done in (A). (C) Interphase and CSF extracts were separated by using phos-tag SDS-PAGE $(15 \mu \mathrm{M}$ phos-tag reagent in $10 \%$ polyacrylamide gel), and immunoblotted for B56 $\gamma, \mathrm{B} " / \mathrm{PR} 48$ and $\mathrm{C} \beta$ subunits of PP2A. For (A) and (B), experiments were performed at least twice. 


\section{Fig. 3 Inhibition by $\mathrm{I1}^{\mathrm{PP2A}}$ and $\mathrm{I}^{\mathrm{PP} 2 \mathrm{~A}}$ are affected by B subunit of PP2A.}

(A) CBB staining of the purified recombinant PP2A complexes and inhibitor proteins. PP2A-B"/PR48 complex was not detected by CBB staining, but was confirmed by immunoblotting (data not shown). Molecular weights are shown on left. (B)(C) Phosphatase activities of PP2A complexes were measured in the presence of recombinant $\mathrm{I}^{\mathrm{PP} 2 \mathrm{~A}}$ and $\mathrm{I}^{\mathrm{PP} 2 \mathrm{~A}}$ proteins (B and C, respectively). Activity of each PP2A complex in the absence of inhibitor proteins was plotted as 100\%. Black squares, PP2A dimer (A and C only); blue circles, PP2A-B558; green triangles, PP2A-B56 $\gamma$; red diamonds, PP2A-B"/PR48. Values are means and error bars indicate standard deviation of three independent experiments. For curve fitting, see Materials and Methods.

Table 1 Summary of $\mathrm{I}^{\mathrm{PP} 2 \mathrm{~A}}$ and $\mathrm{I2}^{\mathrm{PP} 2 \mathrm{~A}}$, s binding to and inhibition for PP2A containing different B subunits. 
Table 1

Table 1

Summary of $\mathrm{I}^{\mathrm{PP} 2 \mathrm{~A}}$ and $\mathrm{I}^{\mathrm{PP} 2 \mathrm{~A}}$, $\mathrm{s}$ binding to and inhibition for

PP2A containing different B subunits.

\begin{tabular}{|c|c|c|c|c|}
\hline & B55 $\delta$ & 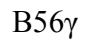 & $\mathrm{B} 56 \varepsilon$ & B”/PR48 \\
\hline \multicolumn{5}{|l|}{$\mathrm{I} 1^{\mathrm{PP} 2 \mathrm{~A}}$} \\
\hline binding & - & - & - & $+{ }^{a}$ \\
\hline inhibition & + & ++ & n.t. & ++ \\
\hline \multicolumn{5}{|l|}{$\mathrm{I} 2^{\mathrm{PP} 2 \mathrm{~A}}$} \\
\hline binding & - & + & - & $+{ }^{a}$ \\
\hline inhibition & ++ & ++ & n.t. & +++ \\
\hline
\end{tabular}

${ }^{\text {a }}$ detectable in M-phase only.

n.t.: not tested 

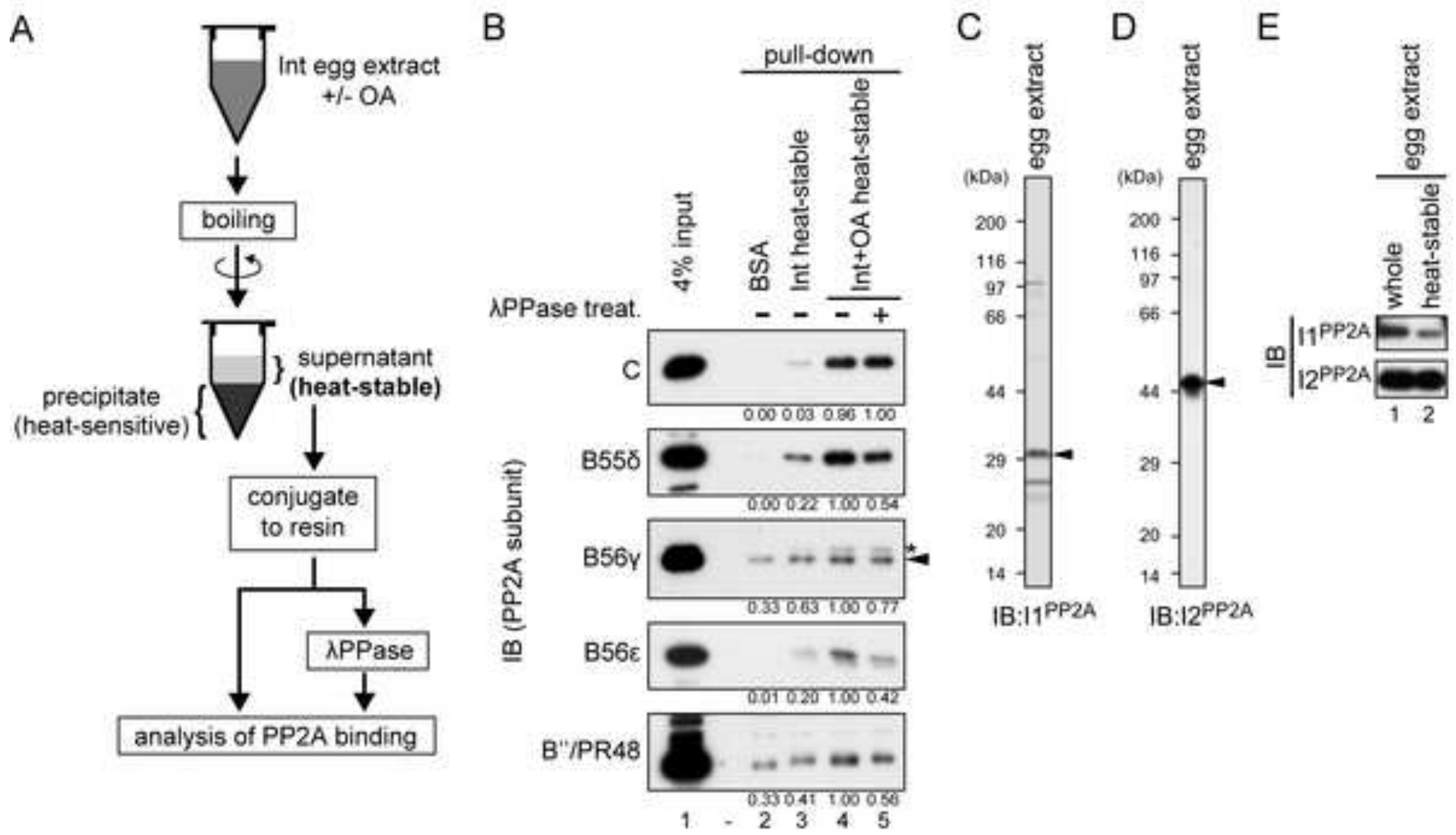

Hino et al.,

Fig. 1 Heat-stable factors of Xenopus egg extract bound PP2A in phopsphorylation-dependent and -independent manners.

(1.5-column fitting image) 
A

B
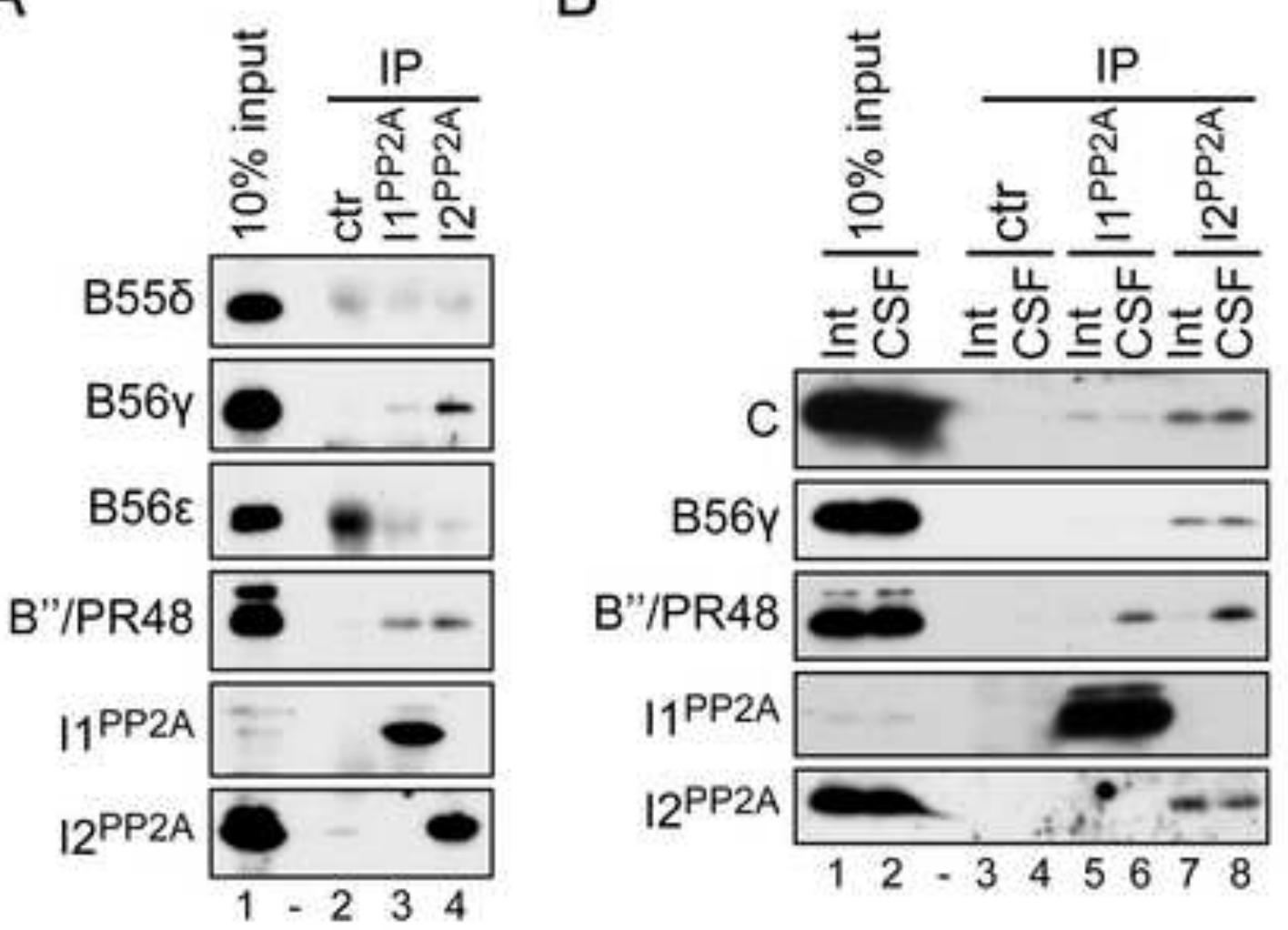

C

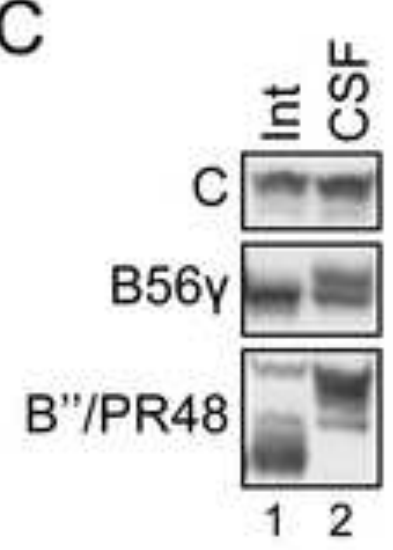

Hino et al.,

Fig. $211^{\mathrm{PP} 2 \mathrm{~A}}$ and $12^{\mathrm{PP} 2 \mathrm{~A}}$ showed binding specificity to $B$ subunits of PP2A.

(single-column fitting image) 
Figure 3
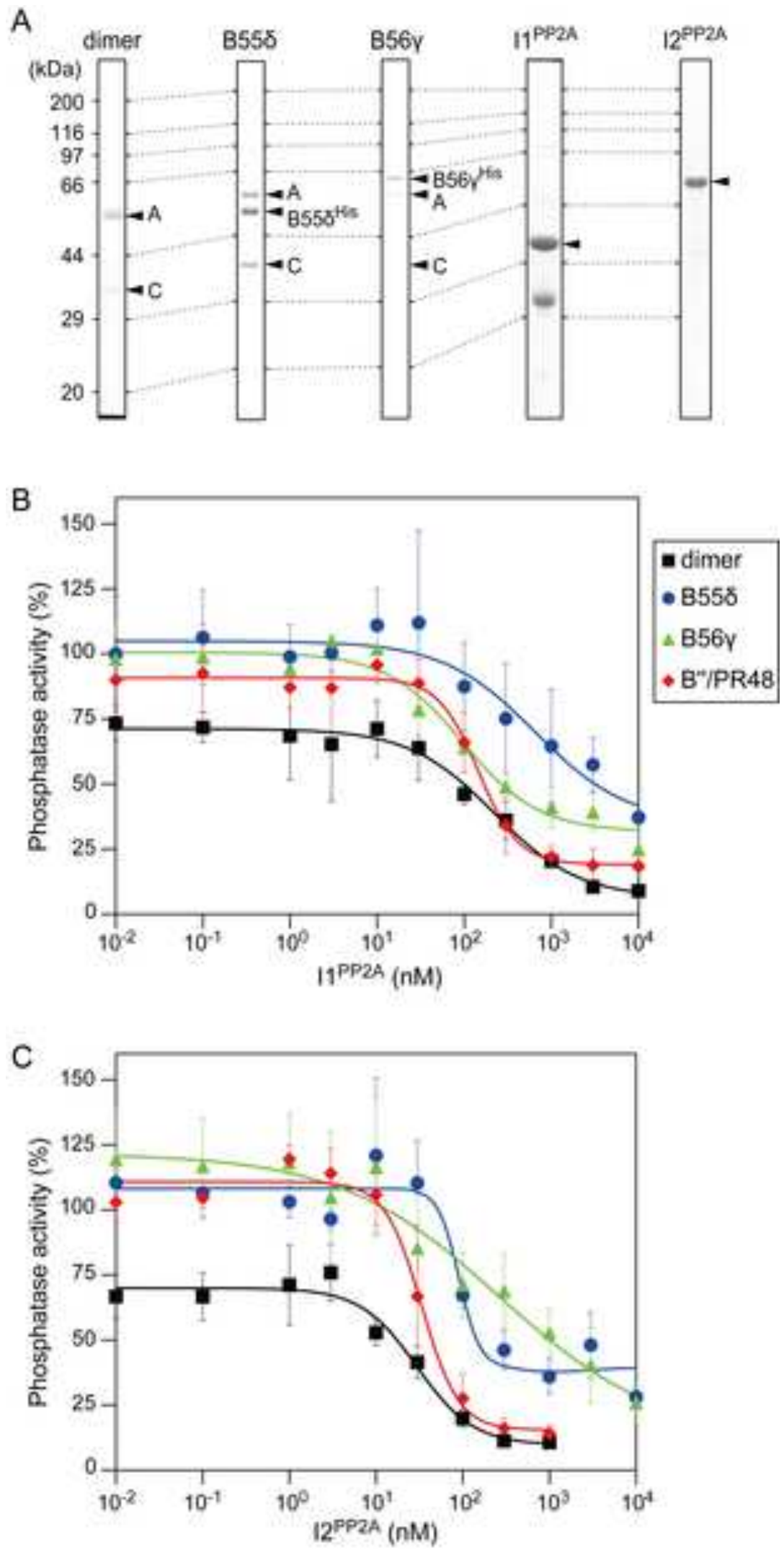

Hino et al.,

Fig. 3 Inhibition by $11^{P p 2 A}$ and $12^{p p 2 A}$ are affected by $B$ subunit of PP2A.

(single-column fitting image) 